\title{
OPTICAL CROP SENSOR FOR VARIABLE-RATE NITROGEN FERTILIZATION IN CORN: I - PLANT NUTRITION AND DRY MATTER PRODUCTION ${ }^{(1)}$
}

\author{
Jardes Bragagnolo(2), Telmo Jorge Carneiro Amado $^{(3)}$, Rodrigo da Silveira Nicoloso ${ }^{(4)}$, \\ Joerg Jasper ${ }^{(5)}$, Junior Kunz ${ }^{(6)}$ \& Tiago de Gregori Teixeira ${ }^{(6)}$
}

\begin{abstract}
SUMMARY
Variable-rate nitrogen fertilization (VRF) based on optical spectrometry sensors of crops is a technological innovation capable of improving the nutrient use efficiency (NUE) and mitigate environmental impacts. However, studies addressing fertilization based on crop sensors are still scarce in Brazilian agriculture. This study aims to evaluate the efficiency of an optical crop sensor to assess the nutritional status of corn and compare VRF with the standard strategy of traditional single-rate $\mathbf{N}$ fertilization (TSF) used by farmers. With this purpose, three experiments were conducted at different locations in Southern Brazil, in the growing seasons 2008/09 and 2010/11. The following crop properties were evaluated: above-ground dry matter production, nitrogen $(N)$ content, $N$ uptake, relative chlorophyll content (SPAD) reading, and a vegetation index measured by the optical sensor N-Sensor ${ }^{\circledR}$ ALS. The plants were evaluated in the stages V4, V6, V8, V10, V12 and at corn flowering. The experiments had a completely randomized design at three different sites that were analyzed separately. The vegetation index was directly related to above-ground dry matter production $\left(R^{2}=0.91 ; p<0.0001\right)$, total N uptake $\left(R^{2}=0.87 ; p<0.0001\right)$ and SPAD reading $\left(R^{2}=0.63 ; p<0.0001\right)$ and inversely related to plant $N$ content $\left(R^{2}=0.53 ; p<0.0001\right)$. The efficiency of VRF for plant nutrition was influenced by the specific climatic conditions of each site. Therefore, the efficiency of the VRF strategy was similar to that of the standard farmer fertilizer strategy at sites 1 and 2 . However, at site 3 where the climatic conditions
\end{abstract}

\footnotetext{
(1) Part of the first author's Masters Dissertation. Received for publication on December 11, 2012 and approved on July $11,2013$.

(2) Doctoral student in Soil Science, Federal University of Santa Maria - UFSM. Av. Roraima, 1000. CEP 97105-900 Santa Maria (RS), Brazil. CAPES Scholarship. E-mail: jardesb@yahoo.com.br

(3) Full Professor at the Soil Science Department, UFSM. CNPq Scholarship. E-mail: telmo.amado@pq.cnpq.br

(4) Researcher at Embrapa Swine and Poultry. Caixa Postal 21. CEP 89700-000 Concórdia (SC), Brazil. E-mail: rodrigo.nicoloso@embrapa.br

(5) Researcher at Yara International ASA, Research Centre. Hanninghof 35. CEP 1464, D-48249 Dülmen, Germany. E-mail: joerg.jasper@yara.com

(6) Master student in Soil Science, UFSM. CAPES Scholarship. E-mail: junioragrokunz@gmail.com, t18t@hotmail.com
} 


\begin{abstract}
were favorable for corn growth, the use of optical sensors to determine VRF resulted in a $12 \%$ increase in $\mathbf{N}$ plant uptake in relation to the standard fertilization, indicating the potential of this technology to improve NUE.
\end{abstract}
Index terms: site-specific management, optical spectrometry, precision agriculture, soil fertility.

\title{
RESUMO: SENSOR ÓPTICO NA FERTILIZAÇAO NITROGENADA À DOSE VARIÁVEL NO MILHO:I-NUTRIÇAO DE PLANTAS E PRODUÇAO DE MATERIA SECA
}

\begin{abstract}
A fertilização nitrogenada à dose variada (FDV) com base em sensores de espectrometria óptica é uma inovação tecnológica que pode incrementar a eficiência do uso do nitrogênio (NUE) e reduzir seu impacto ambiental. Porém, ainda são escassas as pesquisas sobre a utilização desses sensores na agricultura brasileira. Este estudo teve como objetivo avaliar a eficiência do sensor óptico de planta (N-Sensor $\left.{ }^{\circledR} A L S\right)$ em estimar o estado nutricional do milho e comparar a eficiência da fertilização nitrogenada à dose variada prescrita com o sensor óptico com o método-padrão com dose uniforme. Este trabalho foi composto por três experimentos conduzidos nas safras agrícolas de 2008 / 09 e de 2010 / 11, em que se avaliou a resposta do milho à fertilização nitrogenada, comparando-se a dose variada prescrita pelo sensor óptico com a dose uniforme. Os atributos avaliados foram: produção de matéria seca, teor de nitrogênio (N) na matéria seca, absorção total de $N$, teor de clorofila relativo (SPAD) na folha e índice de vegetação determinado com o sensor óptico. As avaliações foram feitas em V4, V8, V10, V12 e florescimento. $O$ experimento foi conduzido em delineamento inteiramente casualizado, com cada local sendo analisado isoladamente. $O$ sensor foi eficiente em captar a variabilidade espacial na nutrição de $N$ do milho, no estádio V8. $O$ índice de vegetação do sensor óptico se relacionou diretamente com a produção de matéria seca $\left(R^{2}=0,91 ; p<0,0001\right)$, absorção total de $N\left(R^{2}=0,87 ; p<0,0001\right)$ e a leitura de $S P A D$ na folha $\left(R^{2}=0,63 ; p<0,0001\right)$, mas foi inversamente relacionado com o teor de $N$ na matéria seca $\left(R^{2}=0,53 ; p<0,0001\right) . O$ efeito da fertilização nitrogenada foi influenciado pelas condições climáticas predominantes em cada local. A estratégia FDV apresentou similar eficiência ao sistema tradicional utilizado pelos agricultores nos locais 1 e 2. No entanto, no local 3, onde as condições climáticas foram favoráveis ao desenvolvimento do milho, o sensor óptico na prescrição da FDV proporcionou incremento de $12 \%$ na quantidade de $N$ absorvido pelo milho, em relação à dose uniforme de $N$ tradicionalmente utilizada pelos agricultores, indicando o potencial desta tecnologia na melhoria do NUE.
\end{abstract}

Termos de indexação: manejo sítio-específico, espectrometria óptica, agricultura de precisão, fertilidade do solo.

\section{INTRODUCTION}

Corn yield is highly dependent on the level of agricultural technology and the quality of the crop management (Raun et al., 2011). Generally, soil nitrogen $(\mathrm{N})$ is not sufficient to fully meet the corn $\mathrm{N}$ demand to ensure high grain yields and therefore, supplementary $\mathrm{N}$ sources are required (Amado et al., 2002). Currently, in Southern Brazil, corn N fertilization is established based on the following criteria: soil organic matter (SOM) content, previous crop in the field, and corn yield goal (Amado et al., 2002; CQFSRS/SC, 2004). However, the spatial variability of the soil and crop properties in the field are not taken into account, which may impair an optimal plant nutrition.

The risk of $\mathrm{N}$ leaching, notably under wet tropical and subtropical climate conditions, associated to the spatial variability of soil properties, such as: SOM content (Amado et al., 2009; Casa et al., 2011), horizon thickness (Albuquerque et al., 1996), water content (Delin \& Berglund, 2005; Gregoret et al., 2006), and yield zones (Molin, 2001; Blackmore et al., 2003; Amado et al., 2009; Bramley, 2009) have effects on the $\mathrm{N}$ nutrition status of corn plants in the field. Thus, a traditional single-rate $\mathrm{N}$ fertilization (TSF) may fail to fit the whole field adequately. Therefore, TSF could over-fertilize some sites while others could be underfertilized (Bredemeier \& Schmidhalter, 2005), promoting low $\mathrm{N}$ fertilization efficiency and increasing environmental impacts (Raun et al., 2005).

In precision farming, variable-rate nitrogen fertilization (VRF) based on crop sensors could increase $\mathrm{N}$ fertilization efficiency (Singh et al., 2006; Li et al., 2010). Plant growth is influenced by weather conditions and soil-crop management, and therefore 
plant properties are generally more efficient to determine VRF than soil properties (Povh et al., 2008). Among the plant properties that could be used to define VRF, the following have a higher chance of success: dry matter production, $\mathrm{N}$ uptake and relative chlorophyll content (SPAD) readings (Raun et al., 2005; Rambo et al., 2008). The use of optical spectrometry sensors able to indirectly assess the crop nutritional status in a non-destructive way represents a technological innovation in $\mathrm{N}$ fertilization management (Raun et al., 2001, 2002, 2005; Argenta et al., 2003; Berntsen et al., 2006; Jørgensen \& Jørgensen, 2007; Portz et al., 2012).

Among the optical sensors currently available, the N-Sensor ${ }^{\circledR}$ ALS (Yara International ASA) has been largely used in Europe, especially in Germany and England. This sensor can determine a vegetation index (VI) based on the reflectance of specific light wavebands (wavelengths of 730 and $760 \mathrm{~nm}$ ) even at night, which is related to the crop $\mathrm{N}$ nutrition status (Link et al., 2005; Jasper et al., 2009; Portz et al., 2012). This crop sensor is not sensitive to the cultivar type (Jasper et al., 2009; Portz et al., 2012). In addition, the crop sensor is little affected by the soil type and luminosity level (Heege et al., 2008). The citation of commercial brands doesn't imply in authors preference in relation to similar equipment's manufactured by other companies.

The N-Sensor ${ }^{\circledR}$ ALS performs a large number of readings per hectare, with approximately 10 readings per second $(10 \mathrm{~Hz})$, and is therefore able to capture the crop variability with high spatial resolution (Jasper et al., 2009). The equipment used in our study is an active sensor, with an active light source able to operate at night. This crop sensor has been used in $\mathrm{N}$ fertilization for wheat (Heege et al., 2008), barley (Soderstron et al., 2010), triticale (Zillmann et al., 2006), corn (Tremblay et al., 2009), sugarcane (Singh et al., 2006; Portz et al., 2012), potato (Zebarth et al., 2003), and cotton (Raper et al., 2011).

However, studies on optical crop sensors, which are fixed to fertilizer spreaders and determine VRF, are still at an early stage of development in Brazil. Our study had the objectives to: evaluate the efficiency of the crop sensor to estimate the $\mathrm{N}$ nutritional status and dry matter production of corn, and compare the efficiency of VRF and TSF in plant nutrition.

\section{MATERIAL AND METHODS}

This study was composed of three experiments carried out in rainfed commercial corn fields, two in the 2008/09 season and the third in the 2010/11 growing season. The region of the experiments has a humid subtropical Cfa climate (Köppen, 1948), with frequent drought periods in summer and autumn. The mean annual rainfall is $1,700 \mathrm{~mm}$ and the mean annual temperature $19.5^{\circ} \mathrm{C}$. The soil is classified as Hapludox (Latossolo Vermelho distrófico típico, according to the Brazilian soil classification) (Embrapa, 2006). The description of the experimental sites and the crop management are shown in table 1 , as well as the soil chemical properties and texture characteristics determined in the beginning of the experiments. During the corn-growing season, normal pluvial precipitation volumes were recorded at sites 1 (season 2008/09) and 3 (season 2010/11), but below-average rainfall at site 2 (season 2008/09) (Figure 1).

The corn response to $\mathrm{N}$ fertilization was investigated using urea as $\mathrm{N}$ source. The $\mathrm{N}$ fertilization rates were split in three applications. Thus, the first rate ranging from 20 to $30 \mathrm{~kg} \mathrm{ha}^{-1} \mathrm{~N}$ was applied at corn planting; the second fertilization of 32 to $40 \mathrm{~kg} \mathrm{ha}^{-1} \mathrm{~N}$ was applied at the V4 growth stage; and the third fertilization ranged from 21 to $180 \mathrm{~kg} \mathrm{ha}^{-1} \mathrm{~N}$ and was applied at stage V8 (Table 2). To compare the strategies VRF and TSF, the same N fertilization rate $\left(140 \mathrm{~kg} \mathrm{ha}^{-1} \mathrm{~N}\right)$ was used in both. This $\mathrm{N}$ fertilization rate was based on the recommendation of CQFSRS/SC (2004), for a yield goal of 8 to $9 \mathrm{Mg} \mathrm{ha}^{-1}$ corn grain, in soils with a SOM content of 2.6 to $5.0 \%$ and in succession to the cover crop black oat (Avena strigosa Schreb.).

At site 1, the treatments were laid out in strips $(15 \times 380 \mathrm{~m})$ without replications. For the evaluation of plant properties, nine georeferenced sampling points separated by a distance of $40 \mathrm{~m}$ were used per treatment. At sites 2 and 3, a completely randomized design with three replications was used. Moreover, at site 2, the treatments were arranged in strips ( $20 \times 260 \mathrm{~m})$ with 12 georeferenced sampling points spaced $20 \mathrm{~m}$ apart. At site 3 , the strip size was $36 \times 300 \mathrm{~m}$. The plant properties were assessed at seven georeferenced sampling points spaced $40 \mathrm{~m}$ apart.

The following plant properties were evaluated: above-ground dry matter production, plant $\mathrm{N}$ content, total $\mathrm{N}$ uptake, SPAD reading measured by portable chlorophyll meter (Minolta SPAD $-502^{\circledR}$, MINOLTA) and the vegetation index (VI) determined by the optical crop sensor (N-Sensor ${ }^{\circledR}$ ALS). Dry matter production was evaluated by collecting corn plants from $2 \mathrm{~m}$ in the plant rows, close to each georeferenced sampling point. The whole aboveground plant was collected, dried, weighed, and ground for evaluation of $\mathrm{N}$ content by micro-Kjeldhal wet combustion, according to the method described by Tedesco et al. (1995). The SPAD readings were evaluated in five corn plants per sampling point according the procedure described by Argenta et al. (2001). The corn plant properties were evaluated in the phenological stages V4, V8, V12, and full flowering for sites 1 and 2 , and in V4, V6, V8, V10, V12, and full flowering at site 3 . 
Table 1. Description of the experimental sites, soil chemical and texture characteristics $(0.00-0.10 \mathrm{~m}$ soil layer), and soil and crop management practices

\begin{tabular}{|c|c|c|c|}
\hline & Site 1 & Site 2 & Site 3 \\
\hline Location & Tio Hugo - RS & Cruz Alta - RS & Não-Me-Toque - RS \\
\hline \multirow[t]{2}{*}{ Coordinate } & $\mathrm{S} 28^{\circ} 35^{\prime} 09^{\prime \prime}$ & $\mathrm{S} 28^{\circ} 36^{\prime} 23^{\prime \prime}$ & $\mathrm{S} 28^{\circ} 31^{\prime} 36^{\prime \prime}$ \\
\hline & $\mathrm{W} 52^{\circ} 36^{\prime} 44^{\prime \prime}$ & $\mathrm{W} 53^{\circ} 40^{\prime} 42^{\prime \prime}$ & $\mathrm{W} 52^{\circ} 47^{\prime} 45^{\prime \prime}$ \\
\hline Altitude (m) & 550 & 450 & 550 \\
\hline No-tillage system (year) & 12 & 23 & 15 \\
\hline Crop season & $2008 / 09$ & $2008 / 09$ & $2010 / 11$ \\
\hline Clay $\left(\mathrm{g} \mathrm{kg}^{-1}\right)^{(1)}$ & 640 & 500 & 550 \\
\hline $\mathrm{pH}\left(\mathrm{H}_{2} \mathrm{O}\right) 1: 1$ & 5.8 & 5.1 & 5.8 \\
\hline $\operatorname{SOM}(\%)^{(2)}$ & 2.8 & 3.8 & 3.8 \\
\hline $\mathrm{P}\left(\mathrm{mg} \mathrm{dm} \mathrm{m}^{-3}\right)^{(3)}$ & 16.3 & 17.2 & 12.3 \\
\hline $\left.\mathrm{K}(\mathrm{mg} \mathrm{dm})^{-3}\right)^{(3)}$ & 0.416 & 0.414 & 0.638 \\
\hline $\mathrm{Al}\left(\mathrm{cmol}_{\mathrm{c}} \mathrm{dm}^{-3}\right)^{(4)}$ & 0 & 0.2 & 0 \\
\hline $\mathrm{Ca}\left(\mathrm{cmol}_{\mathrm{c}} \mathrm{dm}^{-3}\right)^{(4)}$ & 6.1 & 5.1 & 7 \\
\hline $\mathrm{Mg}\left(\mathrm{cmol}_{\mathrm{c}} \mathrm{dm}^{-3}\right)^{(4)}$ & 4.6 & 2.1 & 2.2 \\
\hline $\operatorname{CEC~}\left(\mathrm{cmol}_{\mathrm{c}} \mathrm{dm}^{-3}\right)^{(4)}$ & 13 & 12 & 14 \\
\hline Previous crop & Black oat & Wheat & Black oat \\
\hline Seeding date & Sept. 4, 2008 & Dec. 4,2008 & Sept. 10, 2010 \\
\hline Row spacing (m) & 0.45 & 0.70 & 0.50 \\
\hline Population (plant ha ${ }^{-1}$ ) & 55,000 & 70,000 & 67,000 \\
\hline Corn hybrid & Pioneer 30F53 & Pioneer 30F53 & Pioneer $30 \mathrm{~F} 53$ \\
\hline $\mathrm{P}_{2} \mathrm{O}_{5}$ fertilization $\left(\mathrm{kg} \mathrm{ha}^{-1}\right)$ & 70 & 70 & 78 \\
\hline $\mathrm{K}_{2} \mathrm{O}$ fertilization $\left(\mathrm{kg} \mathrm{ha}^{-1}\right)$ & 84 & 45 & 69 \\
\hline
\end{tabular}

(1) Determined by densitometry; ${ }^{(2)}$ determined by Walkley-Black; ${ }^{(3)}$ extracted by Mehlich-1; ${ }^{(4)}$ extracted by $\mathrm{KCl}\left(1 \mathrm{~mol} \mathrm{~L}^{-1}\right)$.

The VRF was determined by the N-Sensor ${ }^{\circledR}$ spectrometry optical sensor and Yara algorithm (Yara International ASA), which determines the $\mathrm{N}$ fertilization rate based on the corn VI. The equipment had a set of two sensors (right and left), consisting of xenon transmitters with high-intensity multispectral rays $(650-1100 \mathrm{~nm})$ and two photodiode receptors that determine VI based on the reflectance at 730 and $760 \mathrm{~nm}$ wavelength.

The optical sensor was attached to the top of a tractor cabin at approximately $3.8 \mathrm{~m}$ above the soil surface. The sensor scanned a strip of $3.0 \mathrm{~m}$ on either side of the tractor, according to the movement of the machine in the field. The angle between the light emitted by the xenon transmitter and the soil surface ranged between 50 and $66^{\circ}$. For the experiments, the VRF applications were divided in two steps: first the plants were scanned to assess the average VI for each treatment. In the second step, this value was used as reference of the average $\mathrm{N}$ rate to be applied per treatment $\left(91 \mathrm{~kg} \mathrm{ha}^{-1} \mathrm{~N}\right.$ at site $1,80 \mathrm{~kg} \mathrm{ha}^{-1} \mathrm{~N}$ at site 2 , and $70 \mathrm{~kg} \mathrm{ha}^{-1} \mathrm{~N}$ at site 3 ). This topdress $\mathrm{N}$ fertilization was complementary to the previous $\mathrm{N}$ fertilizations at planting and crop stage V4. After this calibration routine, the real-time VRF was used. In all fertilizations the sensor operation mode "N-application" was used.
During $\mathrm{N}$ fertilization, the information of the determined $\mathrm{N}$ rate to be applied in the VRF treatment was transmitted by the crop sensor to the on-board controller (Topper $4500^{\circledR}$, Stara, Brasil), and from there to the centrifugal fertilizer spreader (Twister ${ }^{\circledR}$, Stara, Brasil). All data of the operation were recorded. The corn VI was evaluated at the phenological stage V8 for sites 1 and 2, and at the stages V4, V6, V8, $\mathrm{V} 10$, and V12 for site 3 to investigate the relationship with plant properties. However, the N VRF was applied only at stage V8 of the corn plants in all experiments.

The data collected by the optical sensor were then transferred to a geographic information system (Campeiro 7.0, Giotto et al., 2011). Data were filtered with the exclusion of points located outside the plots (positioning errors) as well as the improbable data defined as "outliers". Afterwards, the average readings of the optical sensor in a radius of $10 \mathrm{~m}$ of each georeferenced point were determined to perform correlation analysis with plant properties.

The results were subjected to descriptive analysis and analysis of variance. The means were compared by Turkey's test $(\mathrm{p}<0.05)$ and polynomial regression analysis using the statistical software SISVAR 4.0 (Ferreira, 2000). 

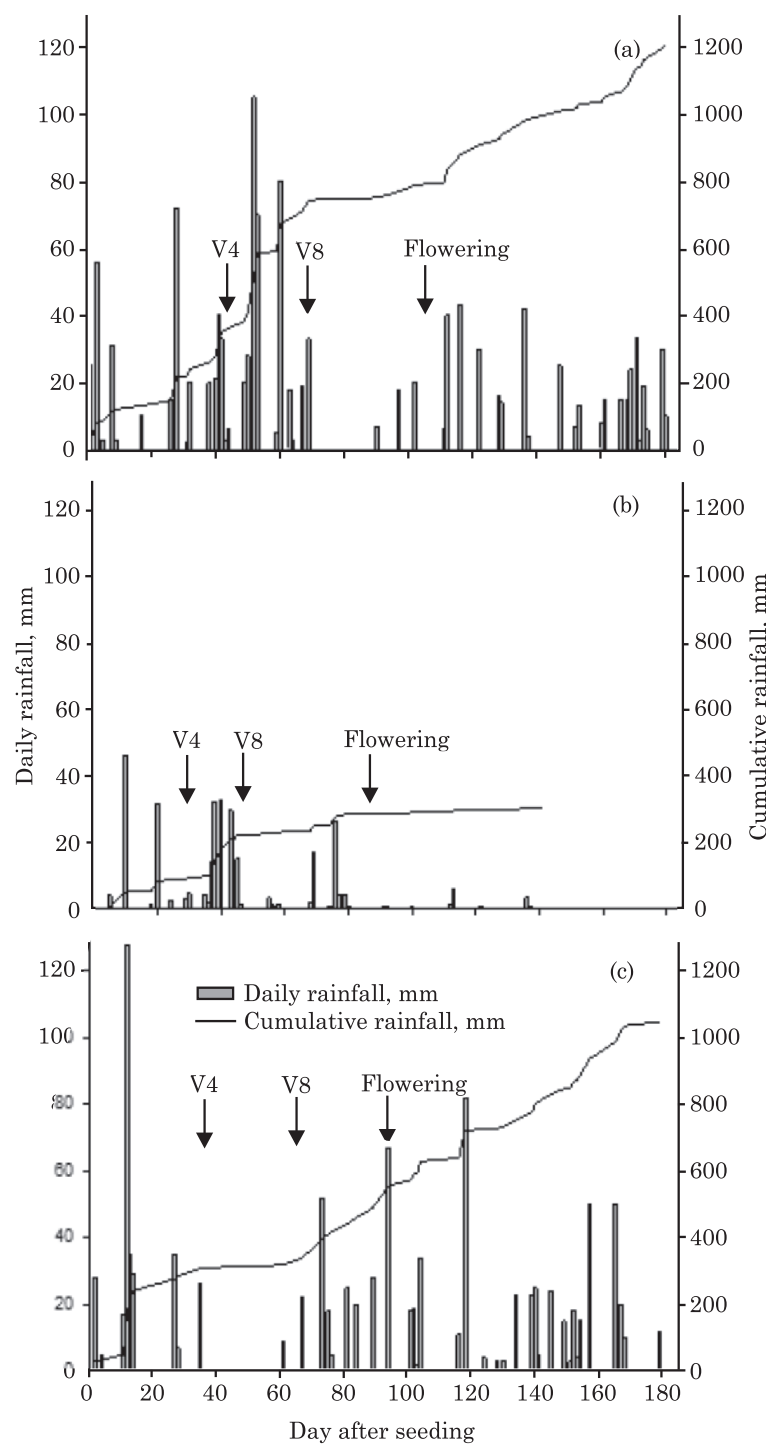

Figure 1. Daily and cumulative rainfall recorded during the corn growing season at sites 1 (a) and 2 (b) during the 2008/09 and at site 3 (c) during the 2010/11 growing season. Source: Cotrijal and Fundacep.

\section{RESULTS AND DISCUSSION}

\section{Corn properties at stage V8}

The corn plant properties evaluated at the phenological stage V8 are presented in table 3. Differences in plant properties, for the same corn phenological stage, were observed among the sites, showing a strong influence of local environmental conditions on crop growth (Figure 1).

On average, dry matter production and the total $\mathrm{N}$ uptake were found to be highest at site 3 and lowest at site 1 . Thus, the corn $\mathrm{N}$ uptake at sites 1 and 2 was 40 and $59 \%$, respectively, in relation to site 3 (Table 3). In addition, lower dry matter production (45 and $83 \%$ ) was verified at sites 1 and 2, respectively, compared to site 3 . The SPAD readings differed less among sites, since the SPAD readings of sites 1 and 2 were 87 and $99 \%$ of those at site 3 , respectively. Most likely, these results can be explained by differences in rainfall patterns with high precipitation in the beginning of the growing season at site 1 and in general, scarce precipitation at site 2 in relation to site 3 (Figure 1). Thus, rainfall at site 1 was unevenly distributed in the period between corn seeding and V8, with a sharp increase in precipitation after the second $\mathrm{N}$ topdressing (V4). The high precipitation recorded in this period could affect corn nutrition due to the leaching of mineral $\mathrm{N}$, thus removing this nutrient from the root zone. Conversely, site 2 had very low precipitation in the same period, which could also compromise corn $\mathrm{N}$ uptake, since adequate soil moisture is essential for SOM mineralization and for the mass flux which is the main mechanism of $\mathrm{N}$ uptake (Barber, 1962; Sangoi \& Almeida, 1994). Precipitation at site 3 was well distributed and in satisfactory quantity to meet the corn demand.

The $\mathrm{N}$ fertilizer treatments at each site only show statistical differences for some plant properties at V8. Although dry matter production at stage V8 varied significantly between sites, a significant increase in dry matter due to $\mathrm{N}$ fertilization was only found at site

Table 2. Nitrogen fertilization strategies used in the experiments

\begin{tabular}{|c|c|c|c|c|c|c|c|c|c|c|c|}
\hline \multicolumn{4}{|c|}{ Site 1} & \multicolumn{4}{|c|}{ Site 2} & \multicolumn{4}{|c|}{ Site 3} \\
\hline \multirow{2}{*}{ Treatment } & \multicolumn{3}{|c|}{$\mathbf{N}$ fertilization } & \multirow{2}{*}{ Treatment } & \multicolumn{3}{|c|}{$\mathbf{N}$ fertilization } & \multirow{2}{*}{ Treatment } & \multicolumn{3}{|c|}{$\mathbf{N}$ fertilization } \\
\hline & Start & V4 & V8 & & Start & V4 & V8 & & Start & V4 & V8 \\
\hline & \multicolumn{3}{|c|}{$\mathrm{kg} \mathrm{ha}^{-1}$} & \multicolumn{4}{|c|}{$\mathrm{kg} \mathrm{ha}^{-1}$} & & \multicolumn{3}{|c|}{$\mathrm{kg} \mathrm{ha}^{-1}$} \\
\hline $27 \mathrm{TSF}$ & 27 & 0 & 0 & $\mathrm{C}$ & 0 & 0 & 0 & $\mathrm{C}$ & 0 & 0 & 0 \\
\hline 80TSF & 27 & 32 & 21 & $140 \mathrm{TSF}$ & 20 & 40 & 80 & 70TSF & 30 & 40 & 0 \\
\hline $120 \mathrm{TSF}$ & 27 & 32 & 61 & $140 \mathrm{VRF}$ & 20 & 40 & 80 & 140TSF & 30 & 40 & 70 \\
\hline $140 \mathrm{TSF}$ & 27 & 32 & 81 & 240TSF & 20 & 40 & 180 & $140 \mathrm{VRF}$ & 30 & 40 & 70 \\
\hline $150 \mathrm{VRF}$ & 27 & 32 & 91 & & & & & 210TSF & 30 & 40 & 140 \\
\hline $160 \mathrm{TSF}$ & 27 & 32 & 101 & & & & & & & & \\
\hline
\end{tabular}

TSF: traditional single-rate $\mathrm{N}$ fertilization; VRF: variable $\mathrm{N}$ fertilization rate using an optical sensor; C: control without $\mathrm{N}$ fertilization. 
Table 3. Descriptive statistics of corn plant properties evaluated at the phenological stage V8

\begin{tabular}{|c|c|c|c|c|}
\hline \multirow{3}{*}{ Treatment } & \multicolumn{4}{|c|}{ Corn plant property } \\
\hline & \multirow{2}{*}{$\frac{\text { Dry matter }}{\mathrm{kg} \mathrm{ha}^{-1}}$} & \multirow{2}{*}{$\begin{array}{c}\text { Chlorophyll } \\
\text { SPAD }\end{array}$} & \multicolumn{2}{|c|}{ Nitrogen } \\
\hline & & & $\%$ & $\mathrm{~kg} \mathrm{ha}^{-1}$ \\
\hline \multicolumn{5}{|l|}{ Site 1} \\
\hline $27 \mathrm{TSF}$ & $658^{\mathrm{ns}}$ & $38.6 \mathrm{c}$ & $2.3^{\mathrm{ns}}$ & $15.5^{\mathrm{ns}}$ \\
\hline 80TSF & 748 & $43.0 \mathrm{~b}$ & 2.4 & 18.4 \\
\hline $120 \mathrm{TSF}$ & 676 & $44.8 \mathrm{ab}$ & 2.6 & 17.7 \\
\hline 140TSF & 728 & $45.3 \mathrm{a}$ & 2.4 & 17.7 \\
\hline $150 \mathrm{VRF}$ & 683 & $44.5 \mathrm{ab}$ & 2.4 & 16.6 \\
\hline 160TSF & 721 & $45.3 \mathrm{a}$ & 2.5 & 17.9 \\
\hline Mean & 702 & 43.6 & 2.4 & 17.3 \\
\hline SD & 31.8 & 2.3 & 0.2 & 3.7 \\
\hline CV (\%) & 0.05 & 0.05 & 0.10 & 0.21 \\
\hline \multicolumn{5}{|l|}{ Site 2} \\
\hline $\mathrm{C}$ & $1297^{\mathrm{ns}}$ & $48.9^{\mathrm{ns}}$ & $1.6 \mathrm{c}$ & $20.9 \mathrm{~b}$ \\
\hline 140TSF & 1260 & 51.0 & $2.0 \mathrm{~b}$ & $25.0 \mathrm{ab}$ \\
\hline $140 \mathrm{VRF}$ & 1303 & 48.0 & $2.0 \mathrm{~b}$ & $26.6 \mathrm{ab}$ \\
\hline 240TSF & 1320 & 51.9 & $2.3 \mathrm{a}$ & $29.9 \mathrm{a}$ \\
\hline Mean & 1292 & 49.8 & 1.9 & 25.7 \\
\hline $\mathrm{SD}$ & 387.3 & 2.5 & 0.2 & 8.9 \\
\hline CV (\%) & 0.29 & 0.05 & 0.15 & 0.35 \\
\hline \multicolumn{5}{|l|}{ Site 3} \\
\hline $\mathrm{C}$ & $1378^{\mathrm{ns}}$ & $48.0 \mathrm{~b}$ & $2.9^{\text {ns }}$ & $40.3^{\mathrm{ns}}$ \\
\hline 70TSF & 1554 & $50.3 \mathrm{ab}$ & $2.9 \mathrm{a}$ & 45.0 \\
\hline 140TSF & 1525 & $51.2 \mathrm{a}$ & $2.7 \mathrm{~b}$ & 41.6 \\
\hline $140 \mathrm{VRF}$ & 1670 & $49.6 \mathrm{ab}$ & $2.7 \mathrm{~b}$ & 45.2 \\
\hline 210TSF & 1581 & $50.7 \mathrm{a}$ & $2.6 \mathrm{~b}$ & 42.2 \\
\hline Mean & 1557 & 50.1 & 2.7 & 43.1 \\
\hline SD & 233.3 & 2.3 & 0.2 & 7.2 \\
\hline CV (\%) & 0.14 & 0.04 & 0.09 & 0.17 \\
\hline
\end{tabular}

TSF: traditional single-rate $\mathrm{N}$ fertilization; VRF: optical sensorbased variable $\mathrm{N}$ fertilization rate; SPAD: portable chlorophyll meter reading; $\mathrm{N}$ : nitrogen content in the dry matter (\%) and total $\mathrm{N}$ uptake $\left(\mathrm{kg} \mathrm{ha}^{-1} \mathrm{~N}\right)$; C: $0 \mathrm{~kg} \mathrm{ha}^{-1} \mathrm{~N}$; SD: standard deviation; $\mathrm{CV}$ : coefficient of variation. Means followed by the same letter in the column at each site are not different by the Tukey test $(\mathrm{p}<0.05) ;{ }^{\mathrm{ns}}$ : not significant.

3. The lack of differences among $\mathrm{N}$ treatments suggests that dry matter might not be a reliable indicator to discriminate $\mathrm{N}$ fertilizer treatments in corn at V8 (Table 3). In addition, the $\mathrm{N}$ uptake at $\mathrm{V} 8$ was also a weak indicator, discriminating only the highest $\mathrm{N}$ rate from the control treatment at site 2 . The $\mathrm{SPAD}$ reading was the most sensitive indicator, able to discriminate the different $\mathrm{N}$ treatments at sites 1 and 3 .

The climatic conditions strongly affected the soil $\mathrm{N}$ dynamic and corn $\mathrm{N}$ nutrition status. Concerning the $\mathrm{N}$ treatments, the average corn $\mathrm{N}$ uptake on at site 3 was approximately $26 \mathrm{~kg} \mathrm{ha}^{-1}$ higher than that observed at site 1 . Thus, the high rainfall registered at site 1 during the initial corn growing stages (721 mm up to stage V8) (Figure 1) probably compromised the $\mathrm{N}$ use efficiency of the starter fertilization ( $\left.27 \mathrm{~kg} \mathrm{ha}^{-1} \mathrm{~N}\right)$ and the first topdress $\mathrm{N}$ fertilization $\left(32 \mathrm{~kg} \mathrm{ha}^{-1} \mathrm{~N}\right)$ due to nitrate leaching (Sangoi et al., 2003; Ceretta et al., 2005). On the other hand, site 3 had accumulated $319 \mathrm{~mm}$ rainfall up to stage V8, i.e., only $44 \%$ of the precipitation at site 1 .

The SPAD readings of $45.4,52.1$, and 55.3 for the crop stages V3-V4, V6-V7, and V10-V11, respectively, were proposed as critical to achieve high corn grain yield (12 $\mathrm{Mg} \mathrm{ha}^{-1}$ ) (Argenta et al., 2003, 2004). In addition, SPAD readings below 53 in the corn stages V8-V9 reported by Godoy et al. (2007) suggested a high probability of plant response to $\mathrm{N}$ fertilization. The average SPAD readings for sites 1,2 , and 3 at V8 were 43.6, 49.8, and 50.1, respectively (Table 3). Therefore, all treatments investigated in our study were below the critical values for SPAD readings.

\section{Corn $\mathbf{N}$ nutrition status and plant properties in relation to the vegetation index determined by an optical crop sensor}

The efficiency of VRF, among other factors, depends on the capability of the crop sensor to accurately estimate the crop nutritional status. The relationship between the corn plant properties at different growing stages and the readings of the optical crop sensor (VI) are presented in figure 2 . This figure only shows data from site 3 because at this site, the crop sensor was used in a large range of phenological corn stages, totalizing 436 observations.

The corn VI was positively correlated with the $\mathrm{N}$ uptake, above-ground dry matter production and SPAD readings (Figure 2), and negatively with the plant $\mathrm{N}$ content. This result is possibly related with the $\mathrm{N}$ dilution effect (Plénet \& Lemaire, 1999; Herrmann \& Taube, 2004), where an increase in the plant $\mathrm{N}$ uptake is followed by an increase in dry matter production but not in the same proportion, resulting in a reduced $\mathrm{N}$ content in dry matter (Table $3)$. Thus, the strength of the relationship between the VI and $\mathrm{N}$ content $\left(\mathrm{R}^{2}=0.53 ; \mathrm{p}<0.0001\right)$ is lower than the relationship between the VI and $\mathrm{N}$ uptake $\left(\mathrm{R}^{2}=0.87 ; \mathrm{p}<0.0001\right)$.

In our study (growth stages V4 to V12), high determination coefficients were obtained for VI and dry matter $\left(R^{2}=0.91 ; p<0.0001\right)$, and for VI and $N$ uptake $\left(R^{2}=0.87 ; p<0.0001\right)$. In general, the values observed in this study were close to those reported by Portz et al. (2012), who investigated the relationship of this optical crop sensor with dry matter production and $\mathrm{N}$ uptake of sugarcane $\left(R^{2}=0.74\right.$ to 0.96$)$.

The relationship between the corn VI and $\mathrm{N}$ uptake is strongly influenced by the respective crop phenological stage (Mutanga \& Skidmore, 2004; Heege et al., 2008; Portz et al., 2012). Thus, for a reliable determination of the nutritional status of crops by optical sensors, the crop must have reached a certain minimum quantity of dry matter production and of $\mathrm{N}$ uptake. On the other hand, the crop sensor should not be used in the late crop 

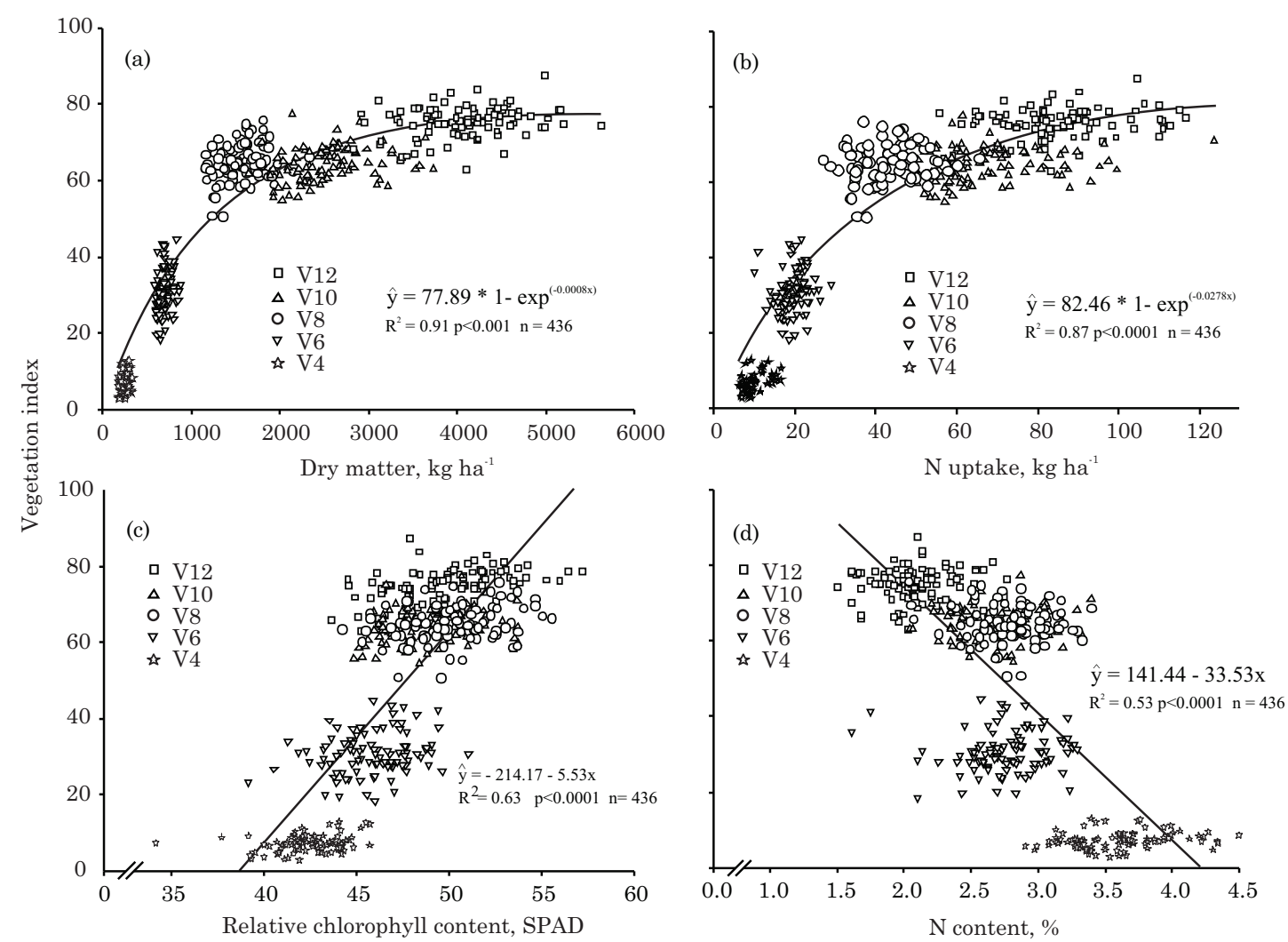

Figure 2. Relationships between corn plant properties and the vegetation index determined by an optical crop sensor (site 3).

stages when there is a saturation of VI readings (Heege et al., 2008; Portz et al., 2012).

A saturation of VI readings in this study was observed in the late phenological stages (up to V10 and V12) of corn. After these crop stages, the increases in dry matter and $\mathrm{N}$ uptake were associated only slightly with increases in VI readings (Figure 2), suggesting a decrease in crop sensor efficiency. Similar results were previously reported by Mutanga \& Skidmore (2004), Povh (2007), Heege et al. (2008), Grohs et al. (2009) and Portz et al. (2012), who reported a gradual loss of efficiency of sensors of optical spectrometry (saturation effect), due to the high dry matter production and closed canopies. A loss of crop sensor efficiency was observed when the dry matter production was higher than $2,500 \mathrm{~kg} \mathrm{ha}^{-1}$ (Figure 2) and $\mathrm{N}$ uptake exceeded $70 \mathrm{~kg} \mathrm{ha}^{-1}$.

\section{Corn $\mathrm{N}$ uptake and dry matter production at flowering affected by $\mathbf{N}$ fertilization strategies}

The corn plant properties at flowering are shown in table 4. The differences among sites reported in stage V8 were amplified at flowering, when site 3 had the highest dry matter production and plant $\mathrm{N}$ uptake. At corn flowering all plant properties showed differences among $\mathrm{N}$ treatments at all sites.

The critical range for plant $\mathrm{N}$ content is $1.0-1.3 \%$, according to Stanford (1973), Grove et al. (1980),
Coelho et al. (1992), and Amado et al. (2002). Most treatments with $\mathrm{N}$ fertilization, regardless of the site, achieved this range, with the exception of the treatment with the lowest $\mathrm{N}$ fertilization rate (80TSF) at site 1 , in the corn flowering stage. On the other hand, the control treatment was generally beyond the adequate range, except for site 3 .

On average, the corn nutrition status at site 3 was better than at the other sites, as expressed by higher plant $\mathrm{N}$ content, $\mathrm{N}$ uptake, and high values of SPAD readings. At this site, even in the control treatment (without $\mathrm{N}$ fertilization) the corn $\mathrm{N}$ uptake reached $117 \mathrm{~kg} \mathrm{ha}^{-1}$, indicating a high soil $\mathrm{N}$ supply. The longterm use of a no-till system ( 15 years) and the SOM content $(3.8 \%)$ (Table 2) associated to favorable climatic conditions for the soil biological activity and corn plant growth could explain the high amount of soil $\mathrm{N}$ uptake.

The $\mathrm{N}$ deficiency noted in the control treatment at site 2 and in the treatment 80TSF at site 1, was less evident at stage V8 (Table 3), but became more pronounced at flowering when the $\mathrm{N}$ demand increased. As a consequence of $\mathrm{N}$ deficiency a lower dry matter, SPAD readings, plant $\mathrm{N}$ content, and $\mathrm{N}$ uptake were noted in those treatments in relation to the treatments with higher $\mathrm{N}$ fertilization rate (Table 4).

The effect of $\mathrm{N}$ fertilization on corn nutrition could be assessed in treatments with the same $\mathrm{N}$ fertilization 
rate. There was a strong effect of the weather conditions of each site on the response in plant nutrition to $\mathrm{N}$ fertilization. Furthermore, the $\mathrm{N}$ uptake at flowering at sites 2 and 1 was 38 and $61 \%$, respectively, of that at site 3 . In addition, the dry matter production was 55 and $85 \%$, respectively, and plant $\mathrm{N}$ content at the same sites was $69 \%$ of that at site 3 .

At site 1, the treatment 140TSF (Table 2) resulted in an increase in $\mathrm{N}$ uptake of $45.6 \mathrm{~kg} \mathrm{ha}^{-1}$ in relation to the control treatment. This increase in $\mathrm{N}$ uptake results in an increase in $2,703 \mathrm{~kg} \mathrm{ha}^{-1}$ of dry matter production. This result was associated to the poor corn $\mathrm{N}$ nutrition status until stage V8 due to the intense

Table 4. Descriptive statistics of corn plant properties evaluated at the phenological stage of full flowering

\begin{tabular}{|c|c|c|c|c|}
\hline \multirow{3}{*}{ Treatment } & \multicolumn{4}{|c|}{ Corn plant property } \\
\hline & \multirow{2}{*}{$\begin{array}{c}\text { Dry matter } \\
\mathrm{kg} \mathrm{ha}{ }^{-1}\end{array}$} & \multirow{2}{*}{$\begin{array}{c}\text { Chlorophyll } \\
\text { SPAD }\end{array}$} & \multicolumn{2}{|c|}{ Nitrogen } \\
\hline & & & $\%$ & $\mathrm{~kg} \mathrm{ha}^{-1}$ \\
\hline \multicolumn{5}{|l|}{ Site 1} \\
\hline $27 \mathrm{TSF}$ & $6113 \mathrm{c}$ & $38.0 \mathrm{c}$ & $0.9 \mathrm{c}$ & $53.2 \mathrm{c}$ \\
\hline $80 \mathrm{TSF}$ & $9350 \mathrm{ab}$ & $41.1 \mathrm{ab}$ & $0.9 \mathrm{c}$ & $96.3 \mathrm{~b}$ \\
\hline $120 \mathrm{TSF}$ & $9390 \mathrm{ab}$ & $45.9 \mathrm{ab}$ & $1.2 \mathrm{~b}$ & $108.8 \mathrm{~b}$ \\
\hline 140TSF & 8816 bc & $47.2 \mathrm{bc}$ & $1.1 \mathrm{~b}$ & $98.8 \mathrm{~b}$ \\
\hline $150 \mathrm{VRF}$ & $10288 \mathrm{ab}$ & $49.1 \mathrm{ab}$ & $1.2 \mathrm{~b}$ & $122.9 \mathrm{~b}$ \\
\hline 160TSF & 12221 a & $52.2 \mathrm{a}$ & $1.4 \mathrm{a}$ & $175.6 \mathrm{a}$ \\
\hline Mean & 9363 & 45.6 & 1.1 & 109.2 \\
\hline $\mathrm{SD}$ & 1820 & 4.7 & 0.2 & 44.4 \\
\hline CV (\%) & 0.19 & 0.10 & 0.19 & 0.40 \\
\hline \multicolumn{5}{|l|}{ Site 2} \\
\hline $\mathrm{C}$ & $5188 \mathrm{c}$ & $41.3 \mathrm{c}$ & $0.6 \mathrm{c}$ & $31.1 \mathrm{c}$ \\
\hline $140 \mathrm{TSF}$ & $5688 \mathrm{bc}$ & $55.1 \mathrm{~b}$ & $1.1 \mathrm{~b}$ & $62.5 \mathrm{~b}$ \\
\hline $140 \mathrm{VRF}$ & $6085 \mathrm{ab}$ & $55.7 \mathrm{ab}$ & $1.1 \mathrm{ab}$ & $66.9 \mathrm{~b}$ \\
\hline $240 \mathrm{TSF}$ & $6268 \mathrm{a}$ & $57.0 \mathrm{a}$ & $1.2 \mathrm{a}$ & $75.2 \mathrm{a}$ \\
\hline Mean & 5823 & 52.9 & 1.0 & 57.3 \\
\hline $\mathrm{SD}$ & 877 & 6.2 & 0.2 & 18.4 \\
\hline CV (\%) & 0.15 & 0.12 & 0.26 & 0.32 \\
\hline \multicolumn{5}{|l|}{ Site 3} \\
\hline $\mathrm{C}$ & $10111 \mathrm{ab}$ & $51.2 \mathrm{~d}$ & $1.2 \mathrm{~d}$ & $117.0 \mathrm{c}$ \\
\hline 70TSF & $8760 \mathrm{c}$ & $54.5 \mathrm{c}$ & $1.3 \mathrm{c}$ & $109.9 \mathrm{c}$ \\
\hline 140TSF & 10417 a & $57.1 \mathrm{~b}$ & $1.6 \mathrm{~b}$ & $163.3 \mathrm{~b}$ \\
\hline $140 \mathrm{VRF}$ & $10180 \mathrm{ab}$ & $57.5 \mathrm{ab}$ & $1.7 \mathrm{ab}$ & $182.6 \mathrm{a}$ \\
\hline 210TSF & $9563 \mathrm{ab}$ & $59.4 \mathrm{a}$ & $1.8 \mathrm{a}$ & $177.2 \mathrm{ab}$ \\
\hline Mean & 9777 & 56.4 & 1.5 & 153.1 \\
\hline $\mathrm{SD}$ & 2027 & 3.8 & 0.3 & 47.8 \\
\hline CV (\%) & 0.20 & 0.06 & 0.22 & 0.31 \\
\hline
\end{tabular}

TSF: traditional single-rate $\mathrm{N}$ fertilization; VRF: optical sensorbased variable $\mathrm{N}$ fertilization rate; SPAD: portable chlorophyll meter reading; $\mathrm{N}$ : nitrogen content in the dry matter (\%) and total $\mathrm{N}$ uptake $\left(\mathrm{kg} \mathrm{ha}^{-1} \mathrm{~N}\right)$; C: $0 \mathrm{~kg} \mathrm{ha}^{-1} \mathrm{~N}$; SD: standard deviation; CV: coefficient of variation. Means followed by the same letter in the same column and site are not different by the Tukey test $(\mathrm{p}<0.05)$. rainfall at this site. As a consequence, the $\mathrm{N}$ uptake in latter crop stages helped to recover the delay in dry matter production. At site 2, the TSF resulted in a significant increase in $\mathrm{N}$ uptake and plant $\mathrm{N}$ content, with a slight increase in dry matter production in relation to the control treatment. This result was associated to the scarce rainfall during the growing season at this site, which affected dry matter production. At site 3, TSF resulted in an increase of $46.3 \mathrm{~kg} \mathrm{ha}^{-1}$ in N uptake with a positive effect in plant $\mathrm{N}$ content and only a slight increase in dry matter production $\left(306 \mathrm{~kg} \mathrm{ha}^{-1}\right)$ in relation to the control treatment.

Averaged across all treatments, the corn $\mathrm{N}$ uptake at sites 2 and 1 was 39 and $71 \%$, respectively, of the quantity verified at site 3 . In addition, the dry matter production measured at site 2 was only $60 \%$ of that at sites 1 and 3 . The SPAD readings averaged 81 and $94 \%$, respectively, for sites 1 and 2 in relation to site 3 (Table 4).

The SPAD readings in the treatments $140 \mathrm{TSF}$, 140VRF, 210TSF (site 3) and 240TSF (site 2) at flowering were similar or superior to the critical value of 57.1 proposed by Argenta et al. (2004). At site 1 no treatments reached this critical value.

The increase in corn $\mathrm{N}$ uptake is one of the main objectives of VRF in relation to TSF, since the spatial redistribution of the $\mathrm{N}$ fertilizer determines higher $\mathrm{N}$ rates in zones where the plant $\mathrm{N}$ nutrition status is poor and therefore there is a higher probability of response to fertilization (Singh et al., 2006). This fact was observed at site 3 , where the quantity of corn $\mathrm{N}$ uptake under VRF was $12 \%$ higher than TSF (Table 4). In addition, the highest corn $\mathrm{N}$ uptake $\left(182.6 \mathrm{~kg} \mathrm{ha}^{-1} \mathrm{~N}\right)$ among all treatments and sites was observed at site 3 under VRF.

The pattern of $\mathrm{N}$ uptake in the different phenological stages of corn was investigated at sites 1 and 3, through intensive plant sampling (Figure 3).

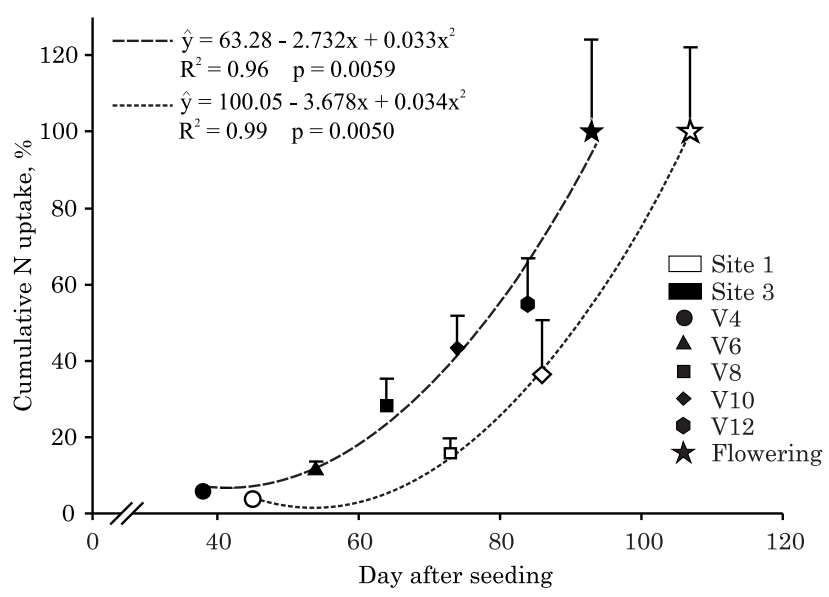

Figure 3. Evolution of the cumulative $\mathbf{N}$ uptake of corn plants at different phenological stages (sites 1 and 3). 
The $\mathrm{N}$ uptake of corn at site 3 was faster than at site 1 , probably due to climatic conditions, as previously discussed. The relative $\mathrm{N}$ uptake until stage V8, averaged across treatments, represented only 16 and $28 \%$ of the total $\mathrm{N}$ uptake at flowering at sites 1 and 3 , respectively (Figure 3 ). Therefore, most of the $\mathrm{N}$ was taken up after stage V8. This result justifies the preferential use of crop sensors after crop stage V8.

\section{CONCLUSIONS}

1. The specific wheather conditions at the study sites had a strong effect on corn $\mathrm{N}$ fertilization efficiency and plant $\mathrm{N}$ nutrition status.

2. The optical crop sensor was efficient in estimating the dry matter production and corn $\mathrm{N}$ uptake, although a loss of efficiency (saturation) was noted in the later crop stages.

3 . The variable-rate $\mathrm{N}$ fertilization based on the optical crop sensor promoted higher corn $\mathrm{N}$ uptake compared to traditional the single-rate $\mathrm{N}$ fertilization at site 3 , where rainfall was favorable to plant growth, indicating the potential of this technology to improve $\mathrm{N}$ use efficiency. At the other sites where there was too much or too little rainfall, there was no difference in the efficiency of $\mathrm{N}$ fertilizer strategies.

4. Considering that most $\mathrm{N}$ was taken up by corn after V8, the use of crop sensors at this or even at later growth stages is a feasible $\mathrm{N}$ fertilization strategy.

\section{ACKNOWLEDGEMENTS}

The authors are indebted to the partner companies STARA, MASSEY FERGUSON, YARA, and COTRIJAL in the Project Aquarius (www.ufsm.br/ projetoaquarius) for the technical support and for providing equipment for this study. They also wish to thank the National Council of Scientific and Technological Development (CNPq) for the scholarship of the second author and financial support to MCT/ CNPq 14/2010 - 480162/2010-7 and MCT/CNPq 14/ 2012 - 485896/2012-5 and CAPES for scholarships of the first, fifth and sixth authors.

\section{LITERATURE CITED}

ALBUQUERQUE, J.A.; REINERT, D.J. \& FIORIN, J.E. Variabilidade de solo e planta em Podzólico VermelhoAmarelo. R. Bras. Ci. Solo, 20:151-157, 1996.

AMADO, T.J.C.; MIELNICZUCK, J. \& AITA, C. Recomendação de adubação nitrogenada para o milho no RS e SC adaptada ao uso de culturas de cobertura do solo, sob sistema de plantio direto. R. Bras. Ci. Solo, 26:241-248, 2002.
AMADO, T.J.C.; PES, L.Z.; LEMAINSKI, C.L. \& SCHENATO, R.B. Atributos químicos e físicos de Latossolos e sua relação com os rendimentos de milho e feijão irrigados. R. Bras. Ci. Solo, 33:831-843, 2009.

ARGENTA, G.; SILVA, P.R.F. \& BORTOLINI, C.G. Clorofila na folha como indicador do nível de nitrogênio em cereais. Ci. Rural, 31:715-722, 2001.

ARGENTA, G.; SILVA, P.R.F.; FOSTHOFER, E.L.; STRIEDER, M.L.; SUHRE, E. \& TEICHMANN, L.L. Adubação nitrogenada em milho pelo monitoramento do nível de nitrogênio na planta por meio do clorofilômetro. R. Bras. Ci. Solo, 27:109-119, 2003.

ARGENTA, G.; SILVA, P.R.F. \& SANGOI, L. Leaf relative chlorophyll content as an indicator parameter to predict nitrogen fertilization in maize. Ci. Rural, 34:1379-1387, 2004.

BARBER, S.A. A diffusion and mass-flow concept of soil nutrient availability. Soil Sci., 93:39-49, 1962.

BERNTSEN, J.; THOMSEN, A.; SCHELDE, K.; HANSEN, O.M.; KNUDSEN, K.; BROGE, N.; HOUGAARD, H. \& HØRFARTER, R. Algorithms for sensor-based redistribution of nitrogen fertilizer in winter wheat. Prec. Agric., 7:65-83, 2006.

BLACKMORE, S.; GODWIN, R.J. \& FOUNTAS, S. The analysis of spatial and temporal trends in yield map data over six years. Biosci. Eng., 84:455-466, 2003.

BRAMLEY, R.G.V. Lessons from nearly 20 years of Precision Agriculture research, development, and adoption as a guide to its appropriate application. Crop Past. Sci., 60:197$217,2009$.

BREDEMEIER, C. \& SCHMIDHALTER, U. Laser-induced chlorophyll fluorescence sensing to determine biomass and nitrogen uptake of winter wheat under controlled environment and field conditions. In: STAFFORD, J.V., ed. PRECISION AGRICULTURE 2005; Proceedings... Wageningen, Academic Publishers, 2005. p.273-280.

CASA, R.; CAVAliERI, A. \& LOCASCIO, B. Nitrogen fertilization management in precision agriculture: A preliminary application example on maize. Italian $\mathrm{J}$. Agron., 6:23-27, 2011.

CERETTA, C.A.; BASSO, C.J.; VIEIRA, F.C.B.; HERBES, M.G.; MOREIRA, I.C.L. \& BERWANGER, A.L. Dejeto líquido de suínos: I. Perdas de nitrogênio e fósforo na solução escoada na superfície do solo, sob plantio direto. Ci. Rural, 35:1296-1304, 2005.

COMISSÃO DE QUÍMICA E FERTILIDADE DO SOLO CCQFSRS/SC. Recomendações de adubação e calagem para os estados do Rio Grande do Sul e Santa Catarina. 3.ed. Passo Fundo, SBCS- Núcleo Região Sul/UFRGS, 2004. 400p.

COELHO, A.M.; FRANÇA, G.E.; BAHIA, A.F.C. \& GUEDES, G.A.A. Doses e métodos de aplicação de fertilizantes nitrogenados na cultura do milho sob irrigação. R. Bras. Ci. Solo, 10:61-67, 1992.

DELIN, S. \& BERGLUND, K. Management zones classified with respect to drought and waterlogging. Prec. Agric., 6:321-340, 2005. 
EMPRESA BRASILEIRA DE PESQUISA AGROPECUÁRIA EMBRAPA. Centro Nacional de Pesquisa de Solos. Sistema brasileiro de classificação do solo, 2.ed. Rio de Janeiro, 2006. 306p.

FERREIRA, D.F. Análises estatísticas por meio do Sisvar para Windows versão 4.0. In: REUNIÃO ANUAL DA REGIÃO BRASILEIRA DA SOCIEDADE INTERNACIONAL DE BIOMETRIA, 45., São Carlos, 2000. Anais... São Carlos, UFSCar, 2000. p.255-258.

GIOTTO, E. Sistema CR - Campeiro 7.0. Available: <http:// www.crcampeiro.net/>. Accessed: Oct. 14, 2011.

GODOY, L.J.G.; SOUTO, L.S.; FERNANDES, D.M. \& VILLAS BÔAS, R.L. Uso do clorofilômetro no manejo da adubação nitrogenada para milho em sucessão a pastagem de Brachiaria decumbens. Ci. Rural, 37:38-44, 2007.

GREGORET, M.C.; DARDANELLI, J.; BONGIOVANNI, R. \& DIAZ-ZORITA, M. Modelo de respuesta sitio-específica del maíz al nitrógeno y agua edáfica en un Haplustol. Ci. Suelo, 24:147-159, 2006

GROVE, L.T.; RITCHEY, K.D. \& NADERMAN JUNIOR, G.C. Nitrogen fertilization of maize on Oxisol of the cerrado of Brasil. Agron. J., 27:261-265, 1980.

GROHS, D.S.; BREDEMEIER, C.; MUNDSTOCK, C.M. \& POLETTO, N. Modelo para estimativa do potencial produtivo em trigo e cevada por meio do sensor Greenseeker. Eng. Agríc., 29:101-112, 2009.

HEEGE, H.J.; REUSCH, S. \& THIESSEN, E. Prospects and results for optical systems for site-specific on-the-go control of nitrogen-top-dressing in Germany. Prec. Agric., 9:115-131, 2008 .

HERRMANN, A. \& TAUBE, F. The range of the critical nitrogen dilution curve for maize (Zea mays L.) can be extended until silage maturity. Agron. J., 96:1131-1138, 2004.

JASPER, J.; REUSCH, S. \& LINK, A. Active sensing of the N status of wheat using optimized wavelength combinationimpact of seed rate, variety and growth stage. In: van HENTEN, E.J.; GOENSE, D. \& LOKHORST, C., eds. PRECISION AGRICULTURE 2009. EUROPEAN CONFERENCE ON PRECISION AGRICULTURE, 7., Wageningen, 2009. Proceedings... Wageningen, Academic Publishers, 2009. p.23-30.

JØRGENSEN, J.R. \& JØRGENSEN, R.N. Uniformity of wheat yield and quality using sensor assisted application of nitrogen. Prec. Agric., 8:63-73, 2007.

KÖPPEN, W.P. Climatologia, com un estúdio de los climas de la tierra. México, Fondo de Cultura Econômica, 1948. 478p.

LI, Y.; CHEN, D.; WALKER, C.N. \& ANGUS, J.F. Estimating the nitrogen status of crops using a digital camera. Field Crops Res., 118:221-227, 2010.

LINK, A.; JASPER, J. \& REUSCH, S. Suitability of different crop parameters for the determination of site-specific nitrogen fertilizer demand. In: STAFFORD, J.V., ed. PRECISION AGRICULTURE; EUROPEAN CONFERENCE ON PRECISION AGRICULTURE, 5., Wageningen, 2005. Proceedings... Wageningen, Academic Publishers, 2005. p.297-302.
MOLIN, J.P. Agricultura de precisão: O gerenciamento da variabilidade. Piracicaba, O Autor, 2001. 83p.

MUTANGA, O. \& SKIDMORE, A.K. Narrow band vegetation indices overcome the saturation problem in biomass estimation. Inter. J. Remote Sens., 25:3999-4014, 2004.

PLÉNET, D. \& LEMAIRE, G. Relationships between dynamics of nitrogen uptake and dry matter accumulation in maize crops. Plant Soil, 216:65-82, 1999.

PORTZ, G.; MOLIN, J.P. \& JASPER, J. Active crop sensor to detect variability of nitrogen supply and biomass on sugarcane fields. Prec. Agric., 13:33-44, 2012.

POVH, F.P. Utilização de sensor ótico ativo em culturas de cereais. Piracicaba, Escola Superior de Agricultura Luiz de Queiroz, 2007. 85p. (Dissertação de Mestrado)

POVH, F.P.; MOLIN, J.P.; GIMENEZ, L.M.; PAULETTI, V.; MOLIN, R. \& SALVI, J.S. Comportamento do NDVI obtido por sensor ótico ativo em cereais. Pesq. Agropec. Bras., 43:1075-1083, 2008.

RAMBO, L.; SILVA, P.R.F.; STRIEDER, M.L.; DELATORRE, C.A.; BAYER, C. \& ARGENTA, G. Adequação de doses de nitrogênio em milho com base em indicadores de solo e planta. Pesq. Agropec. Bras., 43:401-409, 2008.

RAPER, T.B.; VARCO, J.J.; HUBBARD, K.J. \& BOOKER, B.C. Utilization of crop sensors to detect cotton growth and $\mathrm{N}$ stress. In: AMERICAN SOCIETY OF AGRONOMY PROGRAM. ANNUAL MEETING: AGRONOMY FEEDS THE WORLD, 2011. Corpus Christ, Texas. Annual... Corpus Christ, American Society of Agronomy, 2011. p.8-433.

RAUN, W.R.; SOLIE, J.B.; JOHNSON, G.V.; STONE, M.L.; LUKILA, E.; THOMASON, W. \& SHEPERS, J.S. Inseason prediction of potential grain yield in winter wheat using canopy reflectance. Agron. J., 93:131-138, 2001.

RAUN, W.R.; SOLIE, J.B.; JOHNSON, G.V.; STONE, M.L.; MULLEN, R.W.; FREEMAN, K.W.; THOMASON, W. \& LUKILA, E. Improving nitrogen use efficiency in cereal grain production with optical sensing and variable rate application. Agron. J., 98:815-820, 2002.

RAUN, W.R.; SOLIE, J.B.; STONE, M.L.; MARTIN, K.L.; FREEMAN, K.W.; MULLEN, R.W.; ZHANG, H.; SHEPERS, J.S. \& JOHNSON, G.V. Optical sensor-based algorithmic for crop nitrogen fertilization. Commun. Soil Sci. Plant Anal., 36:2759-2781, 2005.

RAUN, W.R.; SOLIE, J.B. \& STONE, M.L. Independence of yield potential and crop nitrogen response. Prec. Agric., 12:508-518, 2011.

SANGOI, L. \& ALMEIDA, M.L. Doses e épocas de aplicação de nitrogênio para a cultura do milho num solo com alto teor de matéria orgânica. Pesq. Agropec. Bras., 29:13-24, 1994.

SANGOI, L.; ERNANI, P.R.; LECH, V.A. \& RAMPAZZO, C. Lixiviação de nitrogênio afetada pela forma de aplicação da uréia e manejo dos restos culturais de aveia em dois solos com texturas contrastantes. Ci. Rural, 33:65-70, 2003.

SINGH, I.; SRIVASTAVA, I.A.; CHANDNA, P. \& GUPTA, R. Crop sensors for efficient nitrogen management in sugarcane: Potential and constraints. Sugar Technol., 8:299-302, 2006 
SODERSTRON, M.; BORJESSON, T.; PETTERSSON, C.G.; NISSEN, K. \& HAGNER, O. Prediction of protein content in malting barley using proximal and remote sensing. Prec. Agric., 11:587-599, 2010.

STANFORD, G. Rationale for optimum nitrogen fertilization in corn production. J. Environ. Qual., 2:159-166, 1973.

TEDESCO, M.J.; GIANELLO, C.; BISSANI, C.A.; BOHNEN, H. \& VOLKWEISS, S.J. Análises de solo, plantas e outros materiais. 2.ed. Porto Alegre, Universidade Federal do Rio Grande do Sul, 1995. 174p.
TREMBLAY, N.; WANG, Z.; MA, B.L.; BELEC, C. \& VIGNEAULT, P. A comparison of crop data measured by two commercial sensors for variable-rate nitrogen application. Prec. Agric., 10:145-161, 2009.

ZEBARTH, B.J.; REES, H.; TREMBLAY, N.; FOURNIER, P. \& LEBLON, B. Mapping spatial variation in potato nitrogen status using the N Sensor. Acta Hortic., 627:267-273, 2003.

ZILLMANN, E.; GRAEFF, S.; LINK, J.; BATCHELOR, W.D. \& CLAUPEIN, W. Assessment of cereal nitrogen requirements derived by optical on-the-go sensors on heterogeneous soils. Agron. J., 98:682-690, 2006. 